\title{
CUL4A Gene
}

National Cancer Institute

\section{Source}

National Cancer Institute. CUL4A Gene. NCI Thesaurus. Code C24324.

This gene is involved in protein degradation. It also plays a role in cell cycle arrest and

DNA repair. 